\title{
Use of Donkey Milk in Cases of Cow's Milk Protein Allergies
}

\author{
Paolo Polidori ${ }^{1{ }^{*},}$, Ambra Ariani ${ }^{2}$ and Silvia Vincenzetti ${ }^{2}$ \\ ${ }^{1}$ School of Pharmacy, University of Camerino, Via Circonvallazione 93, 62024 Matelica (MC), Italy \\ ${ }^{2}$ School of Biosciences and Veterinary Medicine, University of Camerino, Via Circonvallazione 93, 62024 \\ Matelica (MC), Italy
}

\begin{abstract}
Human breast milk is the best nutritional support that insure the right development and influence immune status of the newborn infant. However, when it is not possible to breast feeding may be necessary to use commercial infant formulas that mimic, where possible, the levels and types of vitamins, minerals and other nutrients present in human milk. Despite this, some formula-fed infant develops allergy, atopic disease and differences in response to infection with respect to breast-fed infants. Donkey milk may be considered a good substitute for dairy cow's milk derivatives in feeding children with severe Cow's Milk Protein Allergy (CMPA) since its composition is closer to human milk compared to other species commonly bred. It has been proposed as an alternative to cow's milk for children affected by CMPA when it is not possible breast feeding. Donkey milk is characterized by a low casein content, with values very close to human milk, and also total whey protein content in donkey milk is very close to that found in human milk but higher compared to bovine milk. Donkey milk has been used in several clinical trials involving children affected by CMPA because of the low allergenicity of this milk. The results shown in this review confirmed the nutritional characteristics of the protein fractions of donkey milk and the possibility of using donkey milk in feeding children with CMPA, particularly after an adequate lipid integration, including children with multiple food allergies.
\end{abstract}

Keywords: Donkey milk, Human milk, Cow's Milk Protein Allergy, Milk protein fractions, Lysozyme.

\section{INTRODUCTION}

Milk is considered to be a healthy food, especially for infant nutrition because it contains well-balanced essential and non-essential nutrients (lipids, proteins, amino acids, vitamins and minerals); milk has been present in human diets for thousands of years [1]. Bovine milk is by far the most commonly consumed type of milk, dominating global milk production. However, in certain parts of the world and local contexts, milk from other animal species has a significant share in milk consumption as well.

Compared to other species reared for milk production, donkeys furnish a milk that shows the closest similarity to human milk. Today, donkey milk is difficult to find because donkey breeding is not widespread. Donkey milk has recently stimulated scientific interest for its attractive nutritional characteristics that make it fit to use in the paediatric sphere, in patients affected by cow milk protein allergy (CMPA), as the best alternative to human milk in infant food. In particular, CMPA occurs predominantly in childhood and represents the most common allergy in infants [2]. Potential allergens of cow milk that can cause allergic reactions in the immune-mediated gut of the newborn are caseins and whey proteins $[3,4]$.

*Address correspondence to this author at the School of Pharmacy, University of Camerino, Via Circonvallazione 93, 62024 Matelica (MC), Italy; Tel: +390737-403426; Fax: +39-0737-403402; E-mail: paolo.polidori@unicam.it
Milk of all mammals contains the same principal components, namely water, proteins, fats, carbohydrates, vitamins and minerals, but their content varies widely between ruminant and non-ruminant milk (Table 1). Even within a same species the milk composition may differ considerably, given the influence of genetic factors (not only at species but also at breed level), physiological factors (e.g. lactation stage, milking interval), nutritional factors (e.g. feed energy value and composition) and environmental conditions (e.g. location, season).

Given the strong correlation between nutrition and health, the characterization of the main constituent of food is of fundamental importance: in this context proteins are considered very important nutrients [5]. The total protein content is present in low amounts in donkey milk; in particular, it shows a lower ratio casein/whey protein $[6,7]$. This milk has low levels of casein, and high levels of lactose, unsaturated FA (linoleic and linolenic), and lysozyme. This enzyme is practically absent in ruminant species [8, 9] and has important physiological functions, such as inhibition of growth of certain microorganisms.

\section{COW'S MILK PROTEIN ALLERGY}

The word allergy means an altered or abnormal reaction, that may occur when there is contact between a foreign protein "an allergen" and body tissues, that are sensitive to it [3]. Allergic reactions to mammalian proteins present in foods are quite common, although 
Table 1: Chemical Composition of Mature Milk from Different Mammals [40]

\begin{tabular}{|c|c|c|c|c|c|c|}
\hline & \multirow[t]{2}{*}{ Human } & \multicolumn{2}{|c|}{ Non-ruminants } & \multicolumn{3}{|c|}{ Ruminants } \\
\hline & & Horse & Donkey & Cow & Sheep & Goat \\
\hline Total dry matter $(\mathrm{g} / \mathrm{l})$ & $107-129$ & $93-116$ & $88-117$ & $118-130$ & $181-200$ & $119-163$ \\
\hline Proteins (g/l) & $9-19$ & $14-32$ & $14-20$ & $30-39$ & $45-70$ & $30-52$ \\
\hline Casein/whey ratio & $0.4-0.5$ & 1.1 & 1.28 & 4.7 & 3.1 & 3.5 \\
\hline Fat $(g / l)$ & $21-40$ & $3-42$ & $3-18$ & $33-54$ & $50-90$ & $30-72$ \\
\hline Lactose (g/l) & $63-70$ & $56-72$ & $58-74$ & $44-56$ & $41-59$ & $32-50$ \\
\hline Ash (g/l) & $2-3$ & $3-5$ & $3-5$ & $7-8$ & $8-10$ & $7-9$ \\
\hline Energy (kj/l) & 2843 & $1936-2050$ & $1607-1803$ & $2709-2843$ & $4038-4439$ & $2802-2894$ \\
\hline
\end{tabular}

their actual incidence is uncertain. Allergy to cow's milk and beef is the most frequent adverse reaction, but cases of hypersensitivity to milk and meat from other mammalian species (goat's milk, pork meat, etc) have been described [11]. Cow's Milk Protein Allergy (CMPA) is clinically an abnormal immunological reaction which may be due to the interaction between one or more milk proteins and one or more immune mechanisms, and resulting in immediate IgE-mediated reactions. CMPA chiefly occurs in childhood, involving approximately $3 \%$ of children below the age of 3 years [10].

Cow's milk contains several proteins known to be potential antigens; they can be generally classified in two major groups: caseins and whey proteins. Because $\beta$-lactoglobulin is absent from human milk, it has long been considered the most important of cow's milk allergens [11], but several studies have demonstrated that the casein fraction also has important antigenic potential [11, 12]. Symptoms of CMPA can appear immediately or start several hours or even days after the intake of moderate to large amounts of cow milk or its infant formula. Immediate reactions are mainly lgEdependent, leading to cutaneous, intestinal or respiratory symptoms and in some cases to anaphylactic reaction [13]. Delayed reactions happen after T-cell dependent mechanisms and can be operative both at the skin and the intestinal level [14]. The most frequent symptoms among the common manifestations of CMPA are gastrointestinal, which have been encountered in $50-75 \%$ of patients; respiratory and the skin symptoms are also commonly involved in CMPA [15].

The difference between CMPA and lactose intolerance is of particular interest to many people and is an area which causes much confusion. CMPA is a food allergy, an adverse immune reaction to a food protein that is normally harmless to the non-allergic individual. Lactose intolerance is a non-immunological adverse reaction, due to a lack of the enzyme $\beta$ galactosidase, required to digest the predominant sugar, lactose, in milk. Lactose intolerance manifests as abdominal symptoms and chronic diarrhoea after ingestion of milk, and it is not a disease, about $70 \%$ of the world's population is lactose intolerant [16].

Successful therapy in CMPA depends on completely eliminating cow's milk proteins from the child's diet. Ideally, the replacement food should be hypo- or anallergenic, non cross-reactive with cow's milk, nutritionally adequate and palatable, the latter being fundamental considering the young age of these patients [10]. Extensively hydrolysed formulas are not always tolerated by all these patients, and may also contain residual allergenic epitopes, and all present poor palatability $[17,18]$. Only pure amino-acid formulas are considered to be non-allergenic, but their use is hampered by their unpleasant bitter taste [10, 19]. Although the palatability of soy-protein-based formulas is moderate and they are safe and effective alternatives providing appropriate nutrition [20], they are not generally recommended for the initial treatment of infants and young children with CMPA, in whom soy protein allergy has been reported with frequencies ranging between $17 \%$ and $47 \%[10,20]$. The possibility of using milk from other mammalian species for infants and young children with CMPA has been examined: goat's and sheep's milk are not recommended as their proteins have shown extensive cross-reactivity with CMP both in vitro and in vivo [4, 10, 21].

\section{DONKEY MILK IN HUMAN NUTRITION}

The human infant has a much slower growth rate than other animals, except other primates [22], and the concentration of nutrients in human milk reflects this 
(Table 1). Donkey milk may be a good nutritional source for the neonate when breast milk is unavailable. In this situation, formulas derived bovine milk is used traditionally as substitute for human milk in infant nutrition, but this milk is considerably different from human milk in terms of its macronutrients and micronutrients, and also the absorption rates of vitamins and minerals from the two milks are different, which can be problematic for infants [22]. When a child is affected by CMPA, as mentioned before, the only successful therapy rests upon completely eliminating cow's milk from the child's diet. Considering the possibility of using milk from other mammalian species, also mare's milk appears to be a valid substitute, since its composition is very close to human milk (Table 1). However, mare's milk availability is limited and collection is difficult [22, 23]. Donkeys, as well as horses, belong to the Equus family and this phylogenetic relationship emerges in the similarity of their milk composition (Table 1). Donkey milk has recently aroused scientific interest above all among paediatric allergologists [10, 24, 25, 26]. The choice of substitute for cow's milk in cases of CMPA depends on two major factors: nutritional adequacy and allergenicity, even if cost and taste must also be taken into account. The balance between caseins and whey proteins is an important factor in determining the allergenicity of bovine milk proteins in humans and the modifications of this balance may reduce the allergenicity of bovine milk [22].

\section{DONKEYS' MILK PROTEIN FRACTIONS}

In 1838, a Swedish scientist called Jacob Berzelius suggested the term "protein" after the greek word "proteios", which means "primary" or "of the first rank"; since then, many scientific discoveries have been made about these large molecules indispensable for the good functioning of the body's cells, tissues and organs. In the past, it was believed that the function of proteins was restricted to tissue-formation, while carbohydrates and lipids provided energy to the body. Another out-of-date concept was the belief that dietary proteins were completely hydrolyzed in the gastrointestinal tract and only free amino acids could be adsorbed from the gut. The new concept is that macro- and microelements (such as vitamins and minerals) may interact to perform different functions in the body [27]; amino acids and peptides formed in the digestion of natural proteins are adsorbed and incorporated (anabolism) into various tissues and organs as body proteins.

Milk protein is a very heterogeneous group of molecules and, for ease description, could be classified into five main categories: caseins, whey proteins, milk fat globule proteins, enzymes and other miscellaneous minor proteins [28]. Milk proteins appear to be an exciting link between nutrition, dietetics and therapy. In fact, milk contains a variety of bioactive compounds with special properties associated with the development, growth and survival of infants beyond those provided by nutrition alone [28]. The major antimicrobial proteins in milk are immunoglobulins, lactoferrin, lactoperoxidase and lysozyme [28]. Immunoglobulins (IgG, IgM and secretory $\lg \mathrm{A}$ ) act by a specific mode of action involving antigen-antibody reactions. The other three proteins are non-specific protective factors, and their antimicrobial mechanisms of action differ from each other.

\section{Milk Caseins}

Caseins in milk are those phosphoproteins that precipitate from raw milk after acidification to $\mathrm{pH} 4.6$, whereas the term whey proteins has been used to identify the group of proteins that remains soluble after precipitation of the casein fraction. The content of total caseins and total whey proteins were determined on donkey, sheep and human milk (Table 2), showing a good similarity between human and donkey milk [29]. The bovine casein fraction is composed of four proteins as1-, as2-, $\beta$-, and $\mathrm{k}-\mathrm{CN}$, in proximate proportions of $40 \%, 10 \%, 40 \%$, and $10 \%$, respectively, and as $1-C N$ is a major allergen according to $\lg E$ and $T$ cell recognition data [30]. In the first study conducted on donkey milk protein fractions [6] it was possible to separate and identify $\alpha S 1$-caseins having $\mathrm{N}$-terminal sequence RPKLPHRXPE and variable molecular weights: 30.0 , $31.3,33.0 \mathrm{kDa}$, and $\beta$-caseins, having $\mathrm{N}$-terminal sequence REKEELNVS and molecular weights varying from 33.0 to $37.5 \mathrm{kDa}$. It was not possible to determine

Table 2: Determination of Total Caseins and whey Proteins in Donkey, Sheep and Human Milk [29]

\begin{tabular}{|c|c|c|c|}
\hline & $\begin{array}{c}\text { Donkey } \\
(\mathbf{g} / \mathbf{l})\end{array}$ & $\begin{array}{c}\text { Sheep } \\
\mathbf{( g / / )}\end{array}$ & $\begin{array}{c}\text { Human } \\
(\mathbf{g} / \mathbf{l})\end{array}$ \\
\hline \hline Total whey proteins & 7.50 & 17.0 & 8.00 \\
\hline Total caseins & 6.60 & 39.0 & 5.60 \\
\hline
\end{tabular}


in donkey's milk the presence of other types of caseins, such as $\alpha$ s2-, $\gamma$ - and $k$ - that were found, although in a small amount, in mare's milk. It may be that these caseins in donkey's milk are present in minute, and therefore undetectable quantities, making their characterization difficult. It is important to remind that also in human milk the presence of $\alpha \mathrm{S} 2$ casein has not been demonstrated [8].

\section{Whey Proteins}

The whey proteins content in donkey milk shows a decreasing trend during lactation [31]. The whey proteins content of donkey milk is close to that of human milk, while the average ratio of caseins content to whey proteins is intermediate between the lower value of human milk and the higher value of cow milk [31]. The high whey proteins content of donkey milk makes it more favourable for human nutrition [25, 32]. $\alpha$-lactalbumin plays a key role in lactose synthesis in the mammary gland and provides a major source of essential amino acids in human milk, where it represents the major whey protein [6]. Lysozyme is known to be a natural antimicrobial agent since it catalyses the hydrolysis of glycosidic bonds of mucopolysaccharides in bacterial cell walls. This enzyme, together with other milk bioactive peptides including immunoglobulins, lactoferrin and lactoperoxidase, may function in the infant's digestive tract to reduce the incidence of gastrointestinal infections [33]. The $\alpha$-lactalbumin, $\beta$-lactoglobulin and lysozyme concentrations in donkey milk at different stages of lactation are shown in Table 3.

In the past, $\beta$-lactoglobulin was thought to be present only in the milk of ruminants (cow, buffalo, goat, sheep, etc.) and hence to be the major responsible for allergic reactions to cow milk. Following the discovery and characterization of donkey milk $\beta$ lactoglobulin [6], this protein was found in the majority of milks, but not in human, guinea pig, rabbit or rodent milk. Since then, the role of cow's milk $\beta$-lactoglobulin in eliciting allergic reactions has been re-evaluated and it is now generally accepted that caseins are the major cow's milk protein allergens [34].

\section{CLINICAL TRIALS INVOLVING DONKEY MILK}

With reference to the protein content, it is important to consider the fact that patients who experience an allergy to cow, goat or sheep milk are able to tolerate donkey milk $[10,25,26,35]$. Although the mechanism for tolerance to donkey milk is still unclear, it may be related to the specific levels of major allergenic components in the milk. The balance between caseins and whey proteins played an important role in the sensitization capacity of cow milk and showed that cow milk with a caseins/whey proteins ratio of $40: 60$ was less allergenic than native cow milk [36].

Donkey milk has successfully been used in 1992 for the first time in a clinical study [25] involving 9 children with CMPA, and found to provide nutritional adequacy and good palatability. A second clinical trial was performed in 1999 in a group of 21 children with CMPA and/or multiple food allergy [24]; donkey milk demonstrated to be a safe and valid substitute for cow's milk. Another study performed in 2007 demonstrated that the tolerance of donkey milk in a selected population of children with CMPA was $82.6 \%$ [10]. In the same year, a trial conducted in patients with atopic dermatitis and CMPA showed that the rate of tolerability of donkey milk was $88 \%$ and that donkey milk improved child's eczema [26]. A study in which 25 children with CMPA received fresh donkey milk showed a clinical tolerance in 24 out of $25(96 \%)$ in both patients with IgE- and non-lgE-mediated CMPA [37]. A prospective study was conducted on 92 children with CMPA, diagnosed through a cow's milk elimination diet, followed by double-blind placebo-controlled food challenge [38]. Moreover, $89 \%$ were affected by multiple food allergies, and subjected to very restricted

Table 3: Quantitative Determinations of $\alpha$-Lactalbumin, $\beta$-Lactoglobulin and Lysozyme in Different Stages of Donkey's Lactation [6]

\begin{tabular}{|c|c|c|c|}
\hline Days after Parturition & $\alpha$-lactalbumin (mg/ml) & $\beta$-lactoglobulin (mg/ml) & Lysozyme (mg/ml) \\
\hline \hline 60 & 0.81 & not determined & 1.34 \\
\hline 90 & 1.97 & 4.13 & 0.94 \\
\hline 120 & 1.87 & 3.60 & 1.03 \\
\hline 160 & 1.74 & 3.69 & 0.82 \\
\hline 190 & 1.63 & 3.60 & 0.76 \\
\hline
\end{tabular}


Table 4: Clinical Studies on Tolerability of Donkey Milk in Children with CMPA

\begin{tabular}{|c|c|c|c|}
\hline Children & Age (months range) & Tolerability (\%) & Reference \\
\hline \hline 9 & $0-3$ & 100 & {$[25]$} \\
\hline 21 & 2 & 86 & {$[35]$} \\
\hline 46 & $1-146$ & 82.6 & {$[10]$} \\
\hline 28 & $6-36$ & 88 & {$[26]$} \\
\hline 25 & $6-11$ & 96 & {$[37]$} \\
\hline 92 & $7.5-121.5$ & 90.2 & {$[38]$} \\
\hline
\end{tabular}

diet; 83 children (90.2 \%) liked and tolerated donkey milk, at challenge and during follow-up, with increased Z-scores of weight and length/stature and improved nutritional parameters.

In Table $\mathbf{4}$ are shown the clinical studies in which donkey milk has been used in the treatment of CMPA.

\section{IMPLICATIONS FOR CHILD HEALTH AND NUTRITION}

Donkey milk is the best candidate as substitution of human milk for clinical tolerability, palatability and nutritional adequacy for children affected by CMPA, furnishing additional physiological functions as well, such as providing antibacterial substances, digestive activity molecules, growth factors and hormones.

Extensive clinical trials are needed on the safety profile of any alternative mammal-derived milk. Donkey milk has been used in many clinical trials and it has been demonstrated that can represent a valid feeding solution in children with CMPA, for whom soy-proteinbased formulas, extensively hydrolysed formulas and pure amino-acid formulas were not effective. Donkey milk showed the advantage of being a substitute food palatable and tolerated, as well as being nutritionally valid, with an appropriate lipid integration [39].

The use of natural milk rather than a formula during the cow's milk free diet period should be encouraged, because of its content of functional proteins and peptides that have immunological-like properties and are able to stimulate the functional recovery and development of the neonatal intestine.

In conclusion, the structural similarities between human and donkey milk proteins could contribute to explain the results of clinical studies indicating donkey milk as a valid substitute of cow milk for feeding allergic children. These observations might also constitute the rational for the production of starting formulas based on donkey milk.

\section{REFERENCES}

[1] Lindmark-Mansson $\mathrm{H}$, Akesson $\mathrm{B}$. Antioxidative factors in milk. Brit J Nutr 2000; 84: S103-10.

http://dx.doi.org/10.1017/S0007114500002324

[2] Cosentino C, Paolino R, Freschi P, Calluso AM. Short communication: Jenny milk production and qualitative characteristics. J Dairy Sci 2012; 95: 2910-5. http://dx.doi.org/10.3168/jds.2011-5232

[3] El-Agamy El. The challenge of cow milk protein allergy. Small Rumin Res 2007; 68: 64-72. http://dx.doi.org/10.1016/j.smallrumres.2006.09.016

[4] Vincenzetti S, Foghini L, Pucciarelli S, Polzonetti V, Cammertoni N, Beghelli D, Polidori P. Hypoallergenic properties of donkey's milk: a preliminary study. Veterinaria Ital 2014; 50: 99-107.

[5] Piovesana S, Capriotti AL, Cavaliere C, La Barbera G, Samperi R, Zenezini Chiozzi R, Laganà A. Peptidome characterization and bioactivity analysis of donkey milk. J Proteom 2015; 119: 21-9. http://dx.doi.org/10.1016/j.jprot.2015.01.020

[6] Vincenzetti S, Polidori P, Mariani P, Cammertoni N, Fantuz F, Vita A. Donkey's milk protein fractions characterization. Food Chem 2008; 106: 640-9.

http://dx.doi.org/10.1016/j.foodchem.2007.06.026

[7] Cunsolo V, Muccilli V, Fasoli E, Saletti R, Righetti RG, Foti S. Poppea's bath liquor: the secret proteome of she-donkey's milk. J Proteom 2011; 74: 2083-99. http://dx.doi.org/10.1016/j.jprot.2011.05.036

[8] Miranda G, Mahé MF, Leroux C, Martin P. Proteomic tools to characterize the protein fractions of Equidae milk. Proteomics 2004; 4: 2496-509. http://dx.doi.org/10.1002/pmic.200300765

[9] Polidori P, Beghelli D, Mariani P, Vincenzetti S. Donkey milk production: state of the art. Ital J Anim Sci 2009; 8(Suppl. 2): 677-83.

http://dx.doi.org/10.4081/ijas.2009.s2.677

[10] Monti G, Bertino E, Muratore MC, Coscia A, Cresi F, Silvestro L, Fabris C, Fortunato D, Giuffrida MG, Conti A. Efficacy of donkey's milk in treating highly problematic cows's milk allergic children: An in vivo and in vitro study. Pediatr Allergy Immunol 2007; 18: 258-64. http://dx.doi.org/10.1111/j.1399-3038.2007.00521.x

[11] Restani P, Beretta B, Fiocchi A, Ballabio C, Galli CL. Crossreactivity between mammalian proteins. Ann Allergy Asthma Immunol 2002; 89(Suppl): 11-5. http://dx.doi.org/10.1016/S1081-1206(10)62116-3

[12] Savilahti E, Kuitunen M. Allergenicity of cow milk proteins. J Pediatr 1992; 32: 572-9. http://dx.doi.org/10.1016/s0022-3476(05)81401-5 
[13] Sicherer SH. Determinants of systemic manifestations of food allergy. Allergy Clin Immunol 2000; 106: S251-7. http://dx.doi.org/10.1067/mai.2000.110158

[14] Taylor SL. Immunologic and allergic properties of cow's milk proteins in humans. J Food Prot 1986; 49: 239-50.

[15] Ghosh J, Malhotra GS, Mathur BN. Hypersensitivity of human subjects to bovine milk proteins: a review. Indian $\mathrm{J}$ Dairy Sci 1989; 42: 744-9.

[16] Bindslev-Jensen C. Food Allergy. Brit Med J 1998; 316: 1299-02.

http://dx.doi.org/10.1136/bmj.316.7140.1299

[17] Wahn U, Wahl R, Rugo E. Comparison of the residual allergenic activity of six different hydrolysed protein formulae. J Pediatr 1992; 121: S80-4. http://dx.doi.org/10.1016/S0022-3476(05)81412-X

[18] Ragno V, Giampietro PG, Bruno G, Businco L. Allergenicity of milk proteins hydrolysate formulae in children with cow's milk allergy. Eur J Pediatr 1993; 152: 760-2.

http://dx.doi.org/10.1007/BF01953996

[19] Høst A, Halken S. Hypoallergenic formulas - when, to, whom and how long: after more then 15 years we know the right indication! Allergy 2004; 59: 45-52. http://dx.doi.org/10.1111/j.1398-9995.2004.00574.x

[20] Muraro MA, Giampietro PG, Galli E. Soy formulas and non bovine milk. Ann Allergy Asthma Immunol 2002; 89: 97-101. http://dx.doi.org/10.1016/S1081-1206(10)62132-1

[21] Pessler F, Nejat M. Anaphylactic reaction to goat's milk in a cow's milk - allergic infant. Pediatr Allergy Immunol 2004; 15 : 183-5. http://dx.doi.org/10.1046/j.1399-3038.2003.00087.x

[22] Uniacke-Lowe T, Huppertz T, Fox PF. Equine milk proteins: Chemistry, structure and nutritional significance. Int. Dairy $\mathrm{J}$ 2010; 20: 609-29.

http://dx.doi.org/10.1016/j.idairyj.2010.02.007

[23] Malacarne M, Martuzzi F, Summer A, Mariani P. Protein and fat composition of mare's milk: some nutritional remarks with reference to human and cow's milk. Int Dairy J 2002; 11: 869-77.

http://dx.doi.org/10.1016/S0958-6946(02)00120-6

[24] Carroccio A, Cavataio F, lacono G. Cross-reactivity between milk proteins of different animals. Clin Exp Allergy 1999; 29: 1014-16.

http://dx.doi.org/10.1046/j.1365-2222.1999.00620.x

[25] lacono G, Carroccio A, Cavataio F, Montalto G, Soresi M, Balsamo V. Use of ass's milk in multiple food allergy. J Pediatr Gastroent Nutrit 1992; 14: 177-81. http://dx.doi.org/10.1097/00005176-199202000-00010

[26] Vita D, Passalacqua G, Di Pasquale G, Caminiti L, Crisafulli G, Rulli I, Pajno GB. Ass's milk in children with atopic dermatitis and cow's milk allergy: crossover comparison with goat milk. Pediatr Allergy Immunol 2007; 18: 594-8. http://dx.doi.org/10.1111/j.1399-3038.2007.00567.x

[27] Pacheco MTB, Costa Antunes AE, Sgarbieri VC. New Technological and physiological functional properties of milk proteins. In: Boscoe $A B$, Listow $C R$, editors. Protein Research Progress. New York: Nova Science Publishers Inc 2008; p. 117-68.
[28] Polidori P, Vincenzetti S. Protein profile characterization of donkey milk. In: Hurley WL, editor. Milk Protein. Rijeka: Intechopen.com 2012; p 215-32. http://dx.doi.org/10.5772/45982

[29] Vincenzetti S, Polidori P, Vita A. Nutritional characteristics of donkey's milk protein fraction. In: Ling JR, editor. Dietary Protein Research Trends. New York: Nova Science Publishers Inc 2007; p. 207-25.

[30] Spuergin P, Mueller H, Walter M, Schiltz E, Forster J. Allergenic epitopes of bovine as1-casein recognized by human IgE ad IgG. Allergy 1996; 51: 306-12.

[31] Guo HY, Pang K, Zhang XY, Zhao L, Chen SW, Dong ML, Ren FZ. Composition, physiochemical properties, nitrogen fraction distribution, and amino acid profile of donkey milk. J Dairy Sci 2007; 90: 1635-43. http://dx.doi.org/10.3168/jds.2006-600

[32] Cunsolo V, Costa A, Saletti R, Muccilli V, Foti S. Detection and sequence determination of a new variant betalactoglobulin II from donkey. Rapid Commun Mass Spectrom 2007; 21: 1-9. http://dx.doi.org/10.1002/rcm.2978

[33] Businco L, Gianpietro PG, Lucenti P. Lucaroni F, Pini C, Di Felice G, Lacovacci P, Curadi C, Orlandi M. Allergenicity of mare's milk in children with cow's milk allergy. J Allergy Clin Immun 2000; 105: 1031-4. http://dx.doi.org/10.1067/mai.2000.106377

[34] Docena GH, Fernandez R, Chirdo FG, Fossati CA. Identification of casein as the major allergenic and antigenic protein of cow's milk. Allergy 1996; 51: 412-6. http://dx.doi.org/10.1111/j.1398-9995.1996.tb04639.x

[35] Carroccio A, Cavataio F, Montaldo GD, D'Amico D, Alabrese $\mathrm{L}$, lacono $\mathrm{G}$. Intolerance to hydrolyzed cow's milk protein in infants: clinical characteristics and dietary treatment. Clin Exp Allergy 2000; 30: 1597-03. http://dx.doi.org/10.1046/j.1365-2222.2000.00925.x

[36] Lara-Villoslada F, Olivares M, Xuas J. The balance between caseins and whey proteins in cow's milk determines its allergenicity. J Dairy Sci 2004; 88: 1654-60.

http://dx.doi.org/10.3168/jds.S0022-0302(05)72837-X

[37] Tesse R, Paglialunga C, Braccio S, Armenio L. Adequacy and tolerance to ass's milk in an Italian cohort of children with cow's milk allergy. Ital J Pediatr 2009; 35: 19-22. http://dx.doi.org/10.1186/1824-7288-35-19

[38] Monti G, Viola S, Baro C, Cresi F, Tovo PA, Moro G, Ferrero MP, Conti A, Bertino E. Tolerability of donkey's milk in 92 highly-problematic cow's milk allergic children. J Biol Regul Homeost Agents 2012; (Suppl 3): 75-82.

[39] Martini M, Altomonte I, Salari F, Caroli A. Monitoring quality of Amiata donkey milk: Effects of lactation and productive season. J Dairy Sci 2014; 97: 6819-22. http://dx.doi.org/10.3168/jds.2014-8544

[40] Claeys WL, Verraes C, Cardoen S, De Block J, Huyghebaert A, Raes K, Dewettinck K, Herman L. Consumption of raw or heated milk from different species: An evaluation of the nutritional and potential health benefits. Food Control 2014; 42: 188-201. http://dx.doi.org/10.1016/j.foodcont.2014.01.045 